law only required that cremations take place in a building. Even if Article 14 was engaged, this too would be justified for the same reasons as for Article 9. Cranston J held that, if there had been a violation of the ECHR, it would not have been possible to give a Convention-compatible reading to the 1902 Act and the 2008 Regulations, since that would require the adoption of a meaning inconsistent with the fundamental feature of the legislation or its underlying thrust. The claimant's arguments based on the Race Relations Act 1976 and the Equality Act 2006 were dismissed on the basis of the exemption in both statutes for acts done with statutory authority.

This case note was supplied by Russell Sandberg and is a lightly edited version of a case summary prepared for Law and Justice. It is reproduced here with permission.

doi:10.1017/So956618X09990305

\title{
Catholic Care (Diocese of Leeds) v Charity Commission for England and Wales
}

Charity Tribunal: McKenna, President, June 2009

Adoption agency - Equality Act (Sexual Orientation) Regulations - charitable objects

The appellant was a Roman Catholic adoption agency. Prior to the coming into force of the Equality Act (Sexual Orientation) Regulations 2007 ('the Regulations') it had never, for religious reasons, provided adoption services to homosexuals. Regulation 18(1) provides an exemption where a person acts 'in pursuance of a charitable instrument, and the restriction of benefits to persons of [a specified] sexual orientation is imposed by reason of or on the grounds of the provisions of the charitable instrument'. The agency therefore sought the Charity Commission's consent to replace the objects clause in its Memorandum of Association with a new one intended to bring it within the exemption under Regulation 18(1). The Commission refused and the charity appealed.

The tribunal was mindful of the human rights of 'hard-to-place' children and the charity's success with such children but nevertheless ruled that, to allow the appeal, it would have to be satisfied that the public benefit arising from the charity's activities was sufficiently linked to its ability to discriminate on grounds of sexual orientation. The Regulations had to be interpreted as a coherent whole, mindful of the mischief that Parliament had intended to avert. The tribunal concluded that Regulation 18 permitted discrimination by charities only when their activities did not stray into the areas covered by the other regulations. Regulation 18 could not be relied upon to condone activity that was no longer permitted or 
made unlawful by another regulation. The charity had been permitted under Regulation 15 to continue with its activities as described but this had been time limited, expiring in December 2008. The appeal was dismissed because the discrimination proposed by the charity was unlawful under regulations 8 and $14(8)$.

This is an edited version of a case summary prepared by Frank Cranmer for Law and Justice and it is reproduced here with permission. A transcript of the tribunal's interim determination may be found at http://www.charity.tribunals.gov.uk/documents/ decisions/Ruling_on_Preliminary_Question_(13March2009).pdf and of its final determination at http://www.charity.tribunals.gov.uk/documents/decisions/ CatholicCareDecision_16ogv2.pdf. 